\title{
Traditional Medicine for Children among Kaluppini Indigenous People in South Sulawesi
}

\author{
Nurbaya ${ }^{1}$, Wahyu Chandra², Pramesthi Widya Hapsari ${ }^{3}$ \\ 1 Poltekkes Kemenkes Mamuju, Indonesia; e-mail: bukansiti_nurbaya@yahoo.com \\ 2 Jalin Institute, Makassar, Indonesia. E-mail:wahyuch@yahoo.com \\ 3 Universitas Jenderal Soedirman, Indonesia. Email:pw.hapsari@gmail.com
}

\begin{tabular}{|c|c|}
\hline ARTICLE INFO & ABSTRACT \\
\hline $\begin{array}{l}\text { Keywwords: } \\
\text { Child health; Indigenous } \\
\text { health system; Indigenous } \\
\text { people; Traditional birth } \\
\text { attendants; Traditional } \\
\text { medication. } \\
\text { How to cite: } \\
\text { Nurbaya., Chandra, W., } \\
\text { Hapsari, P.W. (2020). } \\
\text { Traditional Medication for } \\
\text { Children Among } \\
\text { Kaluppini Indigenous } \\
\text { People in South Sulawesi. } \\
\text { ETNOSIA: Jurnal } \\
\text { Etnografi Indonesia. 5(2): } \\
\text { 319-331. } \\
\text { DOI: } \\
\text { 10.31947/etnosia.v5i2.9905 }\end{array}$ & $\begin{array}{l}\text { The traditional knowledge about the use of ancestral medicines to cure } \\
\text { children was highly valued by the indigenous community and an } \\
\text { essential part of their indigenous health system. This study aimed to } \\
\text { provide insight into the traditional medication using plant-based } \\
\text { medication to children in an indigenous community in South Sulawesi } \\
\text { Province. This study was conducted in Kaluppini Village, Enrekang } \\
\text { Regency, South Sulawesi. In-depth interviews and focus group } \\
\text { discussions were conducted both in Bahasa Indonesia and the local } \\
\text { language. Informants were traditional birth attendants and mothers of } \\
\text { under-five. This study was carried out from January to June } 2018 \text {. } \\
\text { Data were analyzed using thematic coding. It is found that Kaluppini } \\
\text { mothers have traditional knowledge of treatment. They used kinds of } \\
\text { plants as traditional remedies to cure their children. This traditional } \\
\text { medication named as pembollo' and pejappi. Pembollo' are traditional } \\
\text { plants intended to cure sick children. Kaluppini people believe that } \\
\text { pejappi is a collection of traditional plant that can treat kinds of } \\
\text { illnesses among children, including to prevent them from supernatural } \\
\text { things. Kaluppini indigenous people practice and believe in their } \\
\text { traditional plants to cure their children. Traditional birth attendants } \\
\text { play a crucial role in providing these traditional plants. Information } \\
\text { provided in this study could be a rational basis for health-related } \\
\text { stakeholders to develop programs of health education and promotion } \\
\text { for indigenous communities. }\end{array}$ \\
\hline
\end{tabular}

\section{Introduction}

Based on the United Nations data, there are about 300 million indigenous people spread in more than 70 countries. Indonesia is one of the countries that have hundreds of indigenous communities. Indigenous people are a unique community. They have their own world-view, culture, language, beliefs, customary laws, and traditional knowledge. They mostly live in mountainous and forest areas. The forest is a part of their life and becomes the source of food and livelihood (Montenegro \& Stephens, 2006). This 
condition makes them take more effort to access the primary services of health and social such as health services, education, and transportation.

National and international awareness of the indigenous people increased in recent years. United Nations has guaranteed that indigenous peoples have the right to access traditional medicines to maintain their wellbeing. They have the same right to access health service facilities. But unfortunately, indigenous children rarely enjoy the same health facilities as non-indigenous children. Studies show that children among indigenous people have worse health indicators compare to non-indigenous children, such as a higher rate of infant mortality and rates of illness such as respiratory diseases and diarrheal (Montenegro \& Stephens, 2006). Unicef reported that About $90 \%$ of worldwide deaths among children under five years old caused by pneumonia and diarrheal diseases (Unicef, 2012). It will result a negative outcome that affected children's health status and well-being.

Traditional indigenous medicines have been known and practiced curing diseases and promote the health of indigenous people. The indigenous peoples have traditional medicinal systems that get recognition as alternative treatments, such as Siddha medical system in India or Ayurveda that is popular in some Asian countries, including Nepal, Sri Lanka, and Thailand. Siddha's traditional medication system consisted of plants, minerals, and animal products and was used by Tamil People for generations. This study also found that most people in developing countries took traditional medicine as their primary medication for some reasons, such as cheaper compared to modern medicine. It is easy to get, and mostly due to cultural beliefs (Sen \& Chakraborty, 2017).

Indigenous people and their cultures are unique. The traditional knowledge about the use of ancestral medicines to cure children was highly valued by the indigenous community and an essential part of their indigenous health system. It is passed down for generations through the oral tradition (Krupa, Sureshkumar, Silambarasan, Priyadarshini, \& Ayyanar, 2019). The World Health Organization (WHO) defines traditional medicine is the 'the sum of the knowledge, skills, and practices based on the theories, beliefs, and experiences indigenous to different cultures, whether explicable or not, used in the maintenance of health, as well as in the prevention, diagnosis, improvement or treatment of physical and mental illnesses.' (World Health Organization, 2013). WHO also acknowledges the indigenous traditional medicine as the collection of knowledge and practices, whether physical or supernatural, that used in diagnosing, preventing, or eliminating kinds of illnesses, whether in physical form, mental, and social diseases (World Health Organization, 2019). Traditional medicine is considered the primary health care provider, especially for people in rural and remote areas (Adu-gyamfi \& Adjei, 2019).

There has been a worldwide increase in the use of traditional or natural medicine by using plant or animal products for the past decade. Studies found that $70-80 \%$ of people around the globe have knowledge of traditional plants and used them as their traditional medicine (Uprety, Asselin, Dhakal, \& Julien, 2012). They used it for physical and nonphysical diseases. But, Indonesia has a lack of information on traditional medicines 
among their indigenous. Therefore, our study tried to provide insight into the traditional medication using plant-based medication to children in an indigenous community in South Sulawesi Province. This study was essential to collect information, documenting, and conserve traditional knowledge that crossed from generations through oral traditions. Besides that, this study was supposed to enrich the improvement of modern drugs and information about the Indonesian indigenous health system.

\section{Method}

This study took place in Kaluppini Village, Enrekang Regency, South Sulawesi, where Kaluppini people lived. Enrekang District locates in northern of Makassar, the capital city of South Sulawesi (Fig. 1). Kaluppini indigenous people are one of the communities who still maintain their local wisdom while still carrying out the traditions, culture, and customary rules. Beliefs in traditional birth attendants are one of their ways to maintains their traditions and beliefs.

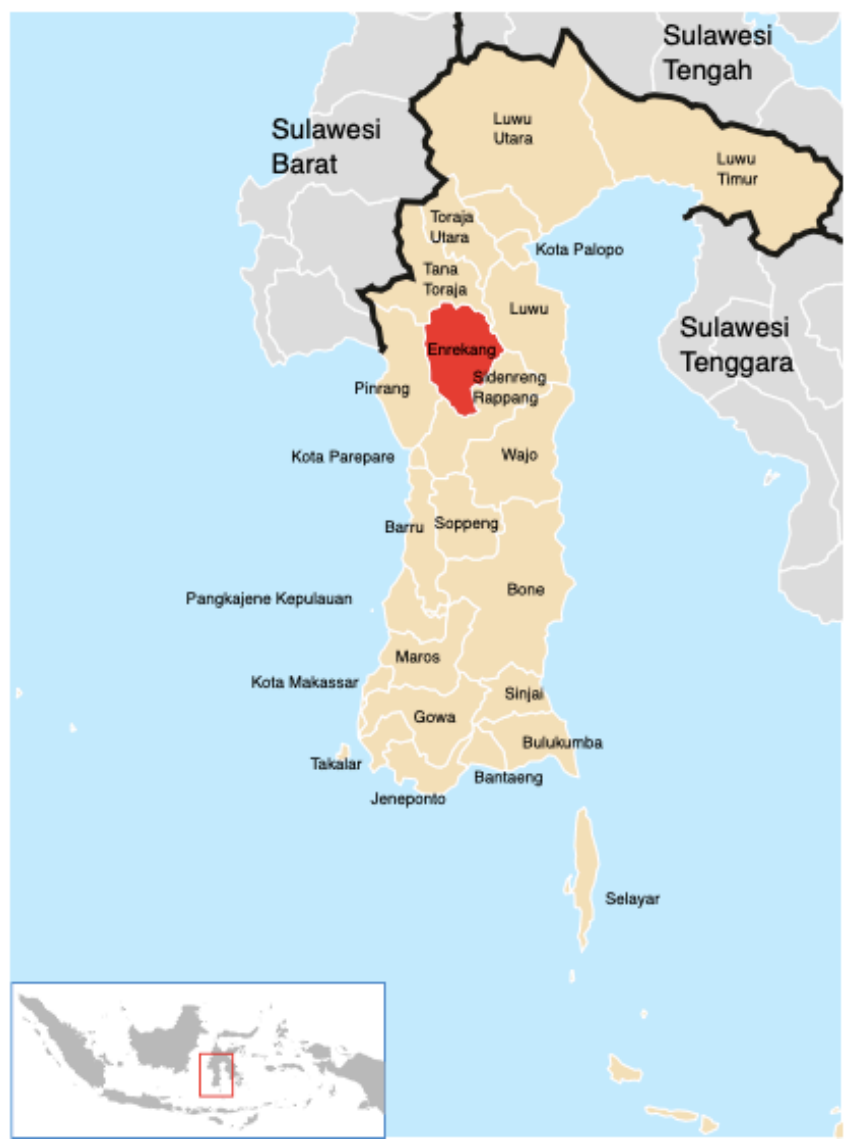

Figure 1. The map of Enrekang District that located in northern of Makassar, the capital city of South Sulawesi (Wikipedia, 2020).

Data collection methods used semi-structure In-depth interviews and focus group discussions. All interviews were conducted in Bahasa Indonesia. But when it was not possible, we used the local language and was undertaken by the local translator who understands the local language and Bahasa Indonesia. The interviews last from 60-90 minutes. 
In the beginning, we conducted focus group discussions to explore community knowledge about the social context within the community and other topics that could be necessary to explore more through personal in-depth interviews. Meanwhile, face-toface in-depth interviews were intended to focus on the viewpoints of the informant about the topics. Pictures and notes were taken during observation. Data was collected in the Kaluppini area from January to June 2018. Informants were traditional birth attendants and mothers of under-five. We obtained information about traditional birth attendants within the community through mothers, local community members, and customary leaders. They were invited to voluntarily participate in this study.

At the end of this study, we interviewed six traditional birth attendants and 67 mothers grouped into 33 in-depth interviews and 6 Focus Group Discussions to gain information about traditional medication applied to the children. Informants must be recognized as Kaluppini indigenous people. This step was to make sure that the data collected was undisputable from Kaluppini people. We selected the informants purposively by using a snowball sampling strategy. All informants had signed written consent and willing to involve this study.

All interviews were recorded using an electronic audio recorder and then transcribed verbatim. The researchers read and re-read the transcripts and discussed with the local assistants to ensure the meanings of the local language were accurate. This step also aimed to gain a general understanding of what informants discussed. It was also to assure the completeness of the voice recording. Analysis of the raw data from verbatim transcribed interviews was analyzed from coding, categorizing until developing the theme. To ensure the robust analysis, we reviewed emerging theme throughout the analysis step. All information gathered remains confidential Anonymity was used in the results study.

\section{Results and Discussion}

\section{About Kaluppini Indigenous People}

Kaluppini people is an indigenous community located in Enrekang District, South Sulawesi. This community still holds strongly in carrying out their tradition and holding rituals. The Kaluppini indigenous people maintain various traditional and religious rituals consistently. They celebrate 13 mandatory rituals within a year that must be performed in a certain order. They also have a ritual called Maccera manurung or Pangewaran (Chandra, 2019). This ritual was the highest tradition in this community that celebrates every eight years. Kaluppini people perform this ceremony based on their beliefs and culture that has become a tradition. It is passed down from generation to generation.

Various traditions developed among Kaluppini people and very thick with Islamic values and symbols that have long last. Such a customary ritual is a way to gratitude the Creator for the blessings of eight years. Various traditions developed among Kaluppini people and very thick with Islamic values and symbols that have long last. Such a customary ritual is a way to gratitude the Creator for the blessings of eight years. The 
ceremony is led by the customary leader. Some rituals reflect the process of human life and are related to the role of traditional birth attendants. Indigenous peoples believed that rituals ceremonies play a crucial role in their wellbeing.

\section{Traditional Medication}

We conducted this study to explore about the traditional medication used by mothers. Mothers in Kaluppini community have a traditional knowledge on treatment. On the site of the study, mothers used kinds of plants as the traditional remedies to cure their children. This traditional medication named as pembollo' and pejappi. Pembollo' is a part of their tradition. As tradition defines as beliefs or behaviors passed down within a community. It could be beliefs, legends, statements, information, customs, etc. that transferred orally from generations (Kistanto, 2016). Meanwhile, the term "traditional knowledge" had some varied terms such as "indigenous knowledge" and "local knowledge". Traditional knowledge meant that a body of knowledge that existed within a community and applied by the local people over some time and passed through generations. It is locally bound, culture and context-specific, non-formal, and orally transmitted, which makes it different from scientific knowledge (Ezeomah \& Farag, 2016).

Pembollo' are traditional plants intended to cure sick children. Kinds of plants that mostly functioned as pembollo' are kunyi', lasuna lea, daun paria, ca'ku, kaju canning, kariango, and panini. These plant medicines will be mixed with water, coconut water, or honey. Studies noted that plant-based medicines come in a variety of forms such as leaves, flowers, stems, roots, seeds, etc. The utilization of plants for medication is known for centuries. Plants are the most used as a source of pharmaceuticals. But we need to remember that children are different form adult people in tolerating traditional medicines. Children are more resistant to some traditional plant medicines such as plants that contain pyrrolizidine alkaloids that may bring toxicity. There is no safe dosage for children (Woolf, 2003). Therefore, mothers need to be careful to feed plants-based traditional medicines to their children.

We also gathered information about the reasons of mothers applied traditional medicine for children. It was due to mothers consider traditional medicines are more original, safer, and accessible. Mothers can find the plants easily near home.

"I only gave traditional medicines to my child because I believed they were safer. I was afraid of the side effects of the drugs that were obtained from the health center" (Mother, 41 years old, Focus Group Discussion)

Mother also stated that traditional medicines were healthier due to it is natural without any chemical contains. It is in line with a study that found indigenous people utilized the traditional medication due to it is cheaper, easier to find near the house, and more sustainable compared to synthetic drugs and pharmaceuticals (Aziz, Khan, Adnan, \& Ullah, 2018). 
Some mothers described their experiences in providing kunyi', lasuna lea, and daun paria that mix with water to medicate their sick children or get a fever. Fever is a common illness suffered by children.

"Usually when children are sick, we give them lasuna lea, kunyi', and daun paria then mixed them all." (Mother, 44 years old, In-depth interviews)

"If we don't have kunyi', we commonly use lasuna lea, and daun paria to be mixed with honey. So that the bitter taste disappears. Those became his pembollo'. Then feed the children. But only a little." (Mother, 33 years old, Focus Group Discussion)

These traditional medicines have various health benefits. For examples kunyi or turmeric (Curcuma longa), it contains rich in polyphenol curcumin. Turmeric is one of the plants that have some benefits for health such as antioxidant, anti-inflammatory, and anticancer. For Asian countries, turmeric is not only for medication but also for culinary needs and for as additional supplements. Even though turmeric is believed has a good impact on health, but studies found that it has a side effect. It could cause headaches, rash, and diarrhea (Jafarirad et al., 2019).

In the time of Covid-19, turmeric is one of the most traditional herbs used by Indonesian people. But there are pros and cons to use of curcumin in preventing Covid-19. Researchers suggested doing more clinical trial studies to confirm the effect of curcumin in preventing the infection of Covid-19 (Nugraha, Ridwansyah, Ghozali, Khairani, \& Atik, 2020). Most traditional medicines have not been subjected to clinical trials. As a result, there remains a lack of knowledge concerning how children are affected by traditional medicines provided by families or traditional birth attendants (Woolf, 2003).
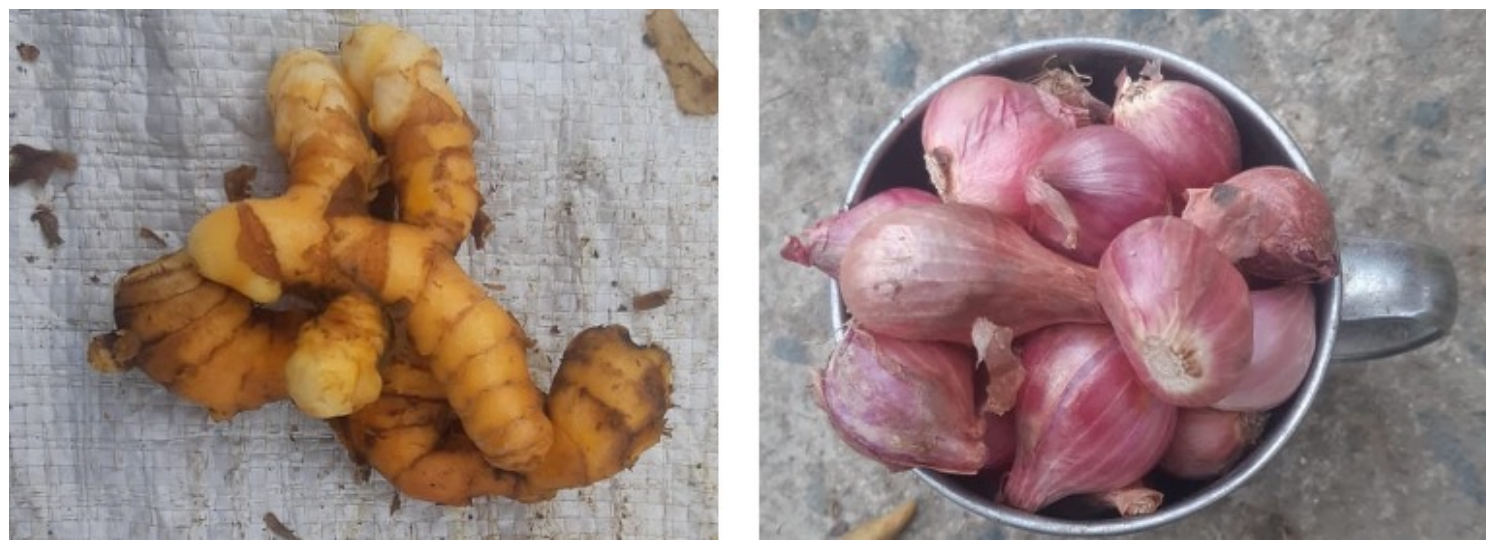

Figure 2 Kunyi' (turmeric) and lasuna lea (onion)

Lasuna lea or onion (Allium cepa L.) has been cultivated for more than 4000 years. It is the original plant from central Asia (Rudrum, 2015). People used it for a long time to treat fever, especially among children. Studies on the use of onions as traditional medicine are found in various studies. Take an example, a study conducted in Indonesia, especially in Western Javanese Culture, mentioned that most parents (86.8\%) used onion mixed with oil to cure their children when got fever and coughs. This study also 
highlighted that the participants consider the utilization of traditional medication to treat fever is safe without any side effects. Onion contains quercetin, antioxidants that acts as an agent to inhibit cancer cells. Studies mentioned that onion is one of the important traditional plant medicines that could be used as a viral infection treatment (Maulida \& Wanda, 2017).

Daun paria or leaves of bitter melon (Momordica charantia) is mostly cultivated in tropical areas such as Indonesia and other Asian countries. Both fruit and leaves of bitter melon contain anti-bacterial action to kill bacteria such as Salmonella and E. coli. Bitter melon leaves have many beneficial outcomes such as to treat stomachache and diarrhea that are mostly suffered by children. Not only leaves, but fruit pulp of bitter melon is also a good source of the nutrient. It contains minerals that are good for the children's development such as magnesium, iron, calcium, and rich in B vitamins (Saeed et al., 2018).

Honey has been used as a traditional medicine in many cultures for decades. It could be classified as a food source and traditional medicines. It is a natural product that has widely used for traditional medicines to maintain health, such as used in Ayurveda traditional medicines. Honey contains antibacterial agents (Arawwawala \& Hewageegana, 2017). It also contains more than 200 nutrients substances, including vitamins, minerals, amino acids, and enzymes. Moreover, the main contents are water and sugar (Eteraf-Oskouei \& Najafi, 2013). Studies reported that consuming honey benefits increased antibody productions that could boost the immune system (El-sound, 2012).

This study also revealed that mothers also believed that if their children's tongue was white, it caused the children lazy to eat and refuse food. Mothers will provide pembollo' cure it. As a mother stated below:

"If the child's tongue is white, usually the child will be lazy to eat. Then we will feed them pembollo'. We use turmeric mixed with honey and then give it to the child a little every day." (Mother, 35 years old, In-depth interviews)

"if my son's tongue is white again. He must be lazy to eat. He will be weak again. So I give him pembollo to get well soon." (Mother, 40 years old, In-depth interviews)

This information about the use of pembollo' was confirmed by sando pea.

"If the child is sick, it is usually given a pembollo'. There are many plants that can be used. Usually turmeric, onion and pariah leaves are most often used when children are sick." (Sando pea 1, In-depth interviews)

White coated tongue could be a sign of the presence of the Candida albicans. Study mentioned that $C$. albicans was found in 54\% infants and 39\% of under-five children. Oral candidiasis among children causes pain and discomfort during the swallow. It will make children refuse to eat and limit their nutritional intake. If it is tolerated, it will cause nutritional problems among children (Patil, Rao, Majumdar, \& Anil, 2015). 
Besides, utilized as pembollo', mothers also stated that they used traditional plants for pejappi. Pejappi is traditional plants that they believe can treat kinds of illnesses among children, including preventing them from supernatural things. The package consists of ca'ku (Kaempferia galanga), kaju canning (Cinnamomum verum), kariango (Acorus calamus Linn.), and panini (Zingiber Purpereum Roxb).

"When the new child was born, sando pea immediately gave me pejappi. Various plants such as ca'ku, kariango, kaju canning, and panini." (Mother, 45 years old, In-depth interviews)

"We keep this pejappi near the baby. and should not be stepped over by a cat" (Mother, 30 years old, Focus Group Discussion)

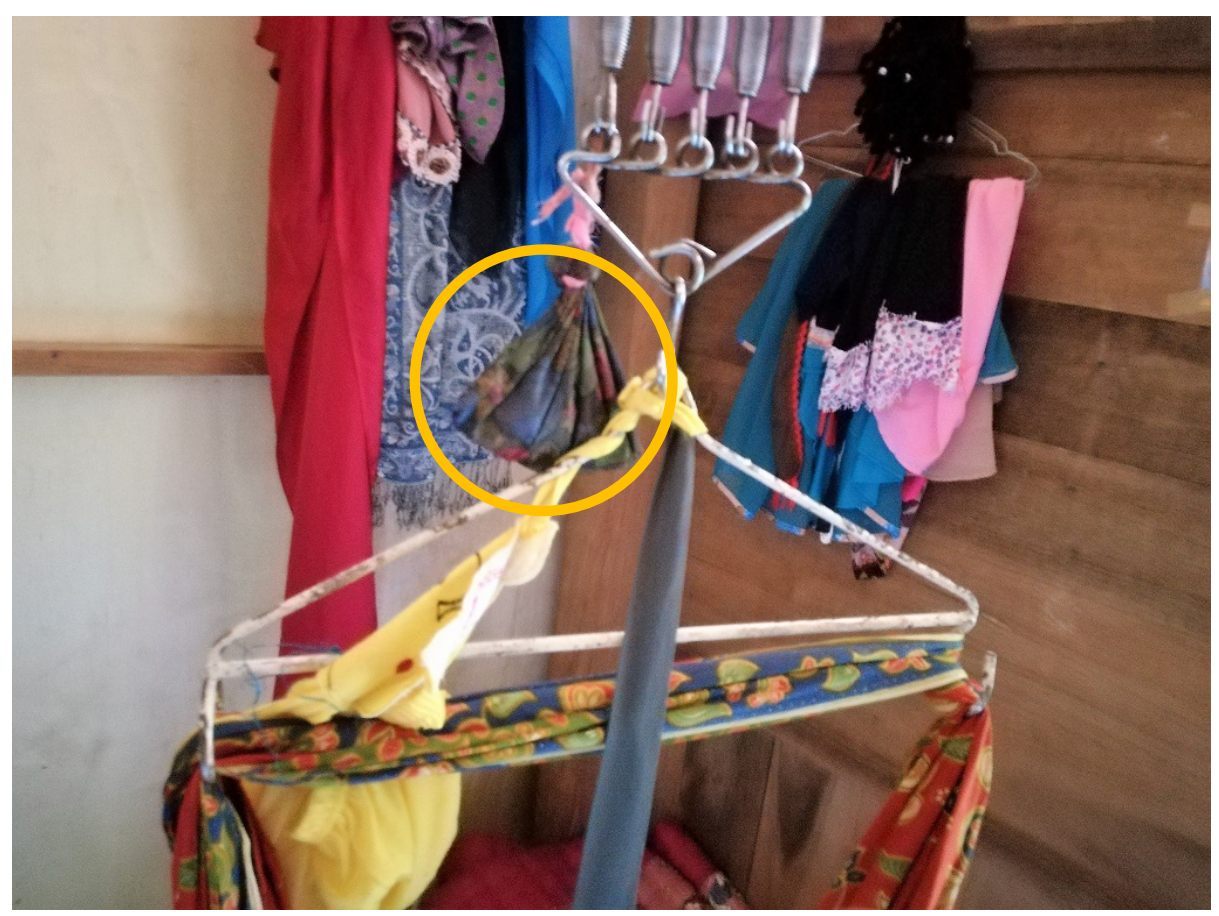

Figure 1 This picture shows how pejappi hang in the child's swing.

This study also found that pembollo' and pejappi was made by the traditional birth attendants and give to mothers soon after delivery. Mothers will put pejappi near the children, pinned in children's clothes, or hang it in the children's swing. Mothers believe pejappi can treat children including from supernatural things as informant stated that: "People say that this pejappi is to protect children from unseen creatures." (Mother, 30 years old, Focus Group Discussion). This study was in line with a study conducted by Cunnama and Honda (2016) that traditional medicine is administered by traditional practitioners, such as traditional birth attendants. In the Eastern Cape of South Africa, traditional practitioner is a person who practice traditional medication to treat traditional illnesses. They are also believed could treat traditional illnesses that arise as a result of supernatural things (Cunnama \& Honda, 2016). 
Other studies also mentioned that they found similar beliefs that some traditional plantbased medicines could have functioned for the supernatural thing (Cheikhyoussef, Mapaure, \& Shapi, 2011). These plant-based traditional medicines are important. Pembollo' is like their first aid at home. This pejappi could also use as a pembollo' when mother could not find another plant and need it immediately. It was found that seeking healthcare from traditional birth attendants is their first choice when their children were sick. It is deeply rooted in the culture of the community. Besides, The World Health Organization recommends that traditional medicine should be considered as one of the sources of healthcare services, especially in remote areas where the availability and accessibility of health services are limited (World Health Organization, 2013).

This study also revealed that several mothers combine pembollo' with modern medicines that they received from midwife. This combination between traditional and modern medication known as ma'pasibali.

"Sometimes, if my child was still sick even after feeding pembollo', I would take my child to the health center. The midwife gave us drugs to treat my child. I applied the drugs while still giving pembollo'. People here called it as ma'pasibali." (Mother, 29 years old, In-depth interviews)

Based on this information, we found that most mothers said they believed in the benefits of traditional medicine and used it in their daily life. Some mothers combined pembollo' with synthetic drugs obtained from health professionals such as a midwife. Previous research has reported that four are three ways mothers treat their sick children. The first is self-medication at the house where mothers provide traditional medicines. The second is using modern treatment by visiting healthcare services or health professionals such as doctors. The third is using an alternative method that they believed contained magic or supernatural power. And the fourth is by seeking treatment through traditional healers (Lucas \& Gilles, 2003). It means that mothers in this community applied all ways to treat their children. Therefore, there needs to be a flexible and innovative approach to encourage indigenous people to determine in what ways they want to improve their health status and well-being.

\section{The role of sando pea to provide pembollo' and pejappi}

Our findings indicate that the use of traditional medicine cannot be separated from the role of the traditional birth attendants in assisting home-delivery of the mother. Traditional birth attendants have been the main human resource within a community to help women childbirth (Rudrum, 2015). In Kaluppini, traditional birth attendants called as sando pea. The term for traditional birth attendants were varied in regions. In Indonesian community, traditional birth attendants have been well-known as dukun anak (Belton, Myers, \& Ngana, 2014). Traditional birth attendants were popular among pregnant mothers for some reasons such as tradition and beliefs.

In many countries especially in ASEAN countries, including Indonesia, traditional birth attendants were commonly known responsible for baby massage (Peltzer \& Pengpid, 2018). They have been a part of the community long before Indonesia government 
promote the Safe Mother-Child Initiative. The participants in this study indicated received strong support for the services that they received from the traditional birth attendants.

"I prefer sando pea because he was the one who helped me give birth. So he already knows all about my child's illnesses." (Mother, 31 years old, In-depth interviews)

Traditional birth attendant or sando pea has an important role in the Kaluppini indigenous health system. Mothers indicate that when their children were sick, they would deliver the children to the sando pea for treatment. Some of the mothers said that they brought some medicinal plants and then concocting it by sando pea. Some others said that the sando pea was the one who immediately prepared the pembollo' then give it to the child.

"If we go to the sando pea, sometimes he gives us pariah leaves. Then he told us to give it to the child." (Mother, 40 years old, In-depth interviews)

Besides, mothers prefer to traditional birth attendants as a result of their experience of the care that they have received from traditional birth attendants since they were pregnant.

"Sometimes I take my child to sando pea or I just make pembollo' from sando pea by myself" (Mother, 41 years old, In-depth interviews).

"I prefer to sando pea when my child was sick. I believe him (sando pea) because he has cared for us (mother and child) since pregnancy." (Mother, 34 years old, Focus Group Discussion)

The role of traditional birth attendants is strong among the Indonesian people, especially among the indigenous community who still cling to beliefs and customs. This prior study is line with many studies that found traditional healer is as an important person in an indigenous community that employing traditional medicinal that combination of medicinal plants and a supranatural power in healing by doing rituals (Kamsani, Franco, \& Slik, 2020). They play an important role in carrying out either in traditional remedies or in some rituals related to children. Traditional birth attendants also can be classified as informal leaders in a society because they can lead rituals and are respected by public.

Ritual ceremony related to maternal and child health were commonly performed in Kaluppini. Previous studies reported that some traditional medication practices were connected with ceremonies and rites that still practiced by indigenous peoples such as Aboriginal people (Uprety et al., 2012). Such as some areas in the western Indonesia, they will perform a naketi ceremony to reduce pain during deliver (Belton et al., 2014).

Another example is balia ritual among Kaili peoples in Central Sulawesi. They believe that diseases are not just merely physical illnesses. It is a metaphysical phenomenon that is related to supernatural experiences. They believed that diseases of illnesses as a warning or even a punishment for what people have done in this universe. They have to perform the balia ritual as a treatment for supernatural diseases. The balia ritual is unique because it was only performed and treated Kaili people only or people whose father or mothers is a Kaili people. This ritual led by a sando, a traditional practitioner (Saprillah, 2017). As in traditional medication practice, the human body is considered as a whole. If 
there is any disharmony both in internal and external part of the body, it will be considered as an illness or disorder (Arji, 2019).

\section{Conclusion}

The above information shows the importance traditional plants medicines to cure children among Kaluppini people. They believed on pembollo' and pejappi to treat all kinds of illnesses in children including to treat from supernatural things. The findings also indicate that Kaluppini people have a strong belief to traditional birth attendants that have a crucial role to providing pembollo' and pejappi. Some plants used as pembollo' are kunyi', lasuna lea, daun paria, ca'ku, kaju canning, kariango, and panini. While plants used for pejappi are ca'ku (Kaempferia galanga), kaju canning (Cinnamomum verum), kariango (Acorus calamus Linn.), and panini (Zingiber Purpereum Roxb).

Traditional medication was popular among pregnant mothers for reasons such as tradition and beliefs. Today, conservation and management of traditional medicinal plants is an important issue worldwide. This traditional medication practice by using traditional plants can be used as a tool to conserve and maintain the biodiversity. It is essential to encourage Kaluppini people to preserve and manage their plant-based traditional medicines. Moreover, the information about beliefs and practices on using traditional medicines will provide a rational basis for health-related stakeholders to develop programs of health education and promotion for indigenous communities.

\section{Acknowledgments}

This work was supported by Neys-van Hoogstraten Foundation, Netherlands. The initial draft of this paper was presented at the International Conference of Wildlife Trade and Utilization in Wallacea Region, titled Pembollo': a concept of plant-based traditional medicine among Kaluppini indigenous people on 22-23 August 2019 hosted by Forestry Faculty, Hasanuddin University, Makassar, South Sulawesi, Indonesia.

\section{Conflicts of interest}

Author declares no conflict of interest.

\section{References}

Adu-gyamfi, S., \& Adjei, R. (2019). Traditional Medicine: Narratives from an Indigenous Population. Mauritus: LAP LAMBERT.

Arawwawala, L. D. A. M., \& Hewageegana, H. G. S. P. (2017). Health Benefits and Traditional Uses of Honey: A Review. Journal of Apitherapy, 2(1), 9. https://doi.org/10.5455/ja.20170208043727

Arji, G. (2019). A systematic literature review and classification of knowledge discovery in traditional medicine. Computer Methods and Programs in Biomedicine, 168, 39-57.

Aziz, M. A., Khan, A. H., Adnan, M., \& Ullah, H. (2018). Traditional uses of medicinal plants used by Indigenous communities for veterinary practices at Bajaur Agency, Pakistan. Journal of Ethnobiology and Ethnomedicine, 14(1), 11.

Belton, S., Myers, B., \& Ngana, F. R. (2014). Maternal Deaths in Eastern Indonesia: 20 Years and Still Walking: An Ethnographic Study. BMC Pregnancy and Childbirth, 14(1). https:/ / doi.org/10.1186/1471-2393-14-39 
Chandra, W. (2019). Ritual Pangewarang: Tahapan, Pantangan, dan Identitas Komunitas Kaluppini di Kabupaten Enrekang. Jurnal Emik, 2(2), 160-179.

Cheikhyoussef, A., Mapaure, I., \& Shapi, M. (2011). The use of some indigenous plants for medical and other purposes by local communities in Namibia with emphasis on Oshikoto Region: a review. Research Journal of Medical Plant, 5(4), 406-419.

Cunnama, L., \& Honda, A. (2016). A mother's choice: a qualitative study of mothers' health seeking behaviour for their children with acute diarrhoea. BMC Health Services Research, 16(1), 1-11. https:/ / doi.org/10.1186/s12913-016-1911-7

El-sound, N. H. A. (2012). Honey between traditional uses and recent medicine. Macedonian Journal of Medical Sciences, 5(2), 205-214. https:/ / doi.org/10.3889/MJMS.1857-5773.2012.0213

Eteraf-Oskouei, T., \& Najafi, M. (2013). Traditional and modern uses of natural honey in human diseases: A review. Iranian Journal of Basic Medical Sciences, 16(6), 731-742. https://doi.org/10.22038/ijbms.2013.988

Ezeomah, B., \& Farag, K. (2016). Effects of development on indigenous dietary pattern: A Nigerian case study. Appetite, 107, 59-68.

Jafarirad, S., Mansoori, A., Adineh, A., Panahi, Y., Hadi, A., \& Goodarzi, R. (2019). Does Turmeric/curcumin supplementation change anthropometric indices in patients with non-alcoholic fatty liver disease? A systematic review and meta-analysis of randomized controlled trials. Clinical Nutrition Research, 8(3), 196.

Kamsani, K., Franco, F. M., \& Slik, F. (2020). A comparative account of the traditional healing practices of healers and non-healers in the Kiudang area of Brunei Darussalam. Journal of Ethnopharmacology, 256(June 2019), 112788.

Kistanto, N. H. (2016). The Javanese slametan as practiced as tradition and identity. International Journal of Humanities and Social Science, 6(11), 290-295.

Krupa, J., Sureshkumar, J., Silambarasan, R., Priyadarshini, K., \& Ayyanar, M. (2019). Integration of traditional herbal medicines among the indigenous communities in Thiruvarur District of Tamil Nadu, India. Journal of Ayurveda and Integrative Medicine, 10(1), 32-37.

Lucas, E. O., \& Gilles, H. M. (2003). Short Textbook of Public Health Medicine for the Tropics. Hodder Arnold (Vol. 14).

Maulida, T. F., \& Wanda, D. (2017). The Utilization of Traditional Medicine to Treat Fever in Children in Western Javanese Culture. Comprehensive Child and Adolescent Nursing, 40(1), 161-168. https:// doi.org/10.1080/24694193.2017.1386985

Montenegro, R. A., \& Stephens, C. (2006). Indigenous Health in Latin America and the Caribbean. The Lancet, 367(9525), 1859-1869.

Nugraha, R. V., Ridwansyah, H., Ghozali, M., Khairani, A. F., \& Atik, N. (2020). Traditional Herbal Medicine Candidates as Complementary Treatments for COVID-19: A Review of Their Mechanisms, Pros and Cons. Evidence-Based Complementary and Alternative 2020. https:// doi.org/10.1155/2020/2560645

Patil, S., Rao, R. S., Majumdar, B., \& Anil, S. (2015). Clinical appearance of oral Candida infection and therapeutic strategies. Frontiers in Microbiology, 6(DEC), 1-10. https://doi.org/10.3389/fmicb.2015.01391

Peltzer, K., \& Pengpid, S. (2018). Traditional health practitioners in Indonesia: Their profile, practice and treatment characteristics. Complementary Medicine Research, 26(2), 93-100. https://doi.org/10.1159/000494457

Rudrum, S. (2015). Traditional Birth Attendants in Rural Northern Uganda: Policy, Practice, and Ethics. Health Care for Women International, 37(2), 250-269. https:/ / doi.org/10.1080/07399332.2015.1020539 
Saeed, F., Afzaal, M., Niaz, B., Arshad, M. U., Tufail, T., Hussain, M. B., \& Javed, A. (2018). Bitter melon (Momordica charantia): A natural healthy vegetable. International Journal of Food Properties, 21(1), 1270-1290. https:/ / doi.org/10.1080/10942912.2018.1446023

Saprillah. (2017). "Balia - Perayu Amuk Dewata": Pengobatan Tradisional di Antara Modernitas dan Agama di Masyarakat Kaili. Etnosia: Jurnal Etnografi Indonesia, 3, 22-47.

Sen, S., \& Chakraborty, R. (2017). Revival, modernization and integration of Indian traditional herbal medicine in clinical practice: Importance, challenges and future. Journal of Traditional and Complementary Medicine, 7(2), 234-244.

Unicef. (2012). Pneumonia and diarrhoea. United Nations Children's Fund. Retrieved from http://www.unicef.org/eapro/Pneumonia_and_Diarrhoea_Report_2012.pdf

Uprety, Y., Asselin, H., Dhakal, A., \& Julien, N. (2012). Traditional use of medicinal plants in the boreal forest of Canada: Review and perspectives. Journal of Ethnobiology and Ethnomedicine, 8(1), 7.

Wikipedia. (2020). Kabupaten Enrekang. Retrieved from https://id.wikipedia.org/wiki/Kabupaten_Enrekang

Woolf, A. D. (2003). Herbal remedies and children: Do they work? Are they harmful? Pediatrics, 112(1 II), 240-246.

World Health Organization. (2013). WHO Traditional Medicine Strategy 2014-2023. World Health Organization.

World Health Organization. (2019). WHO global report on traditional and complementary medicine 2019. World Health Organization. Retrieved from https:/ / apps.who.int/iris/bitstream/handle/10665/312342/9789241515436eng.pdf?ua=1 